\title{
Assessment of Spatial Distribution and Temporal Trends of Precipitation and Its Extremes over Nigeria
}

\author{
Moses Owoicho Audu $^{1 *}$ (), Emmanuel Ejembi ${ }^{2}$, Tertsee Igbawua ${ }^{1}$ \\ ${ }^{1}$ Department of Physics, Joseph Sarwuan Tarka University Makurdi, Nigeria \\ ${ }^{2}$ Department of Natural and Applied Sciences, Namibia University of Science and Technology, Namibia \\ Email: *audumoses53@yahoo.com
}

How to cite this paper: Audu, M. O., Ejembi, E., \& Igbawua, T. (2021). Assessment of Spatial Distribution and Temporal Trends of Precipitation and Its Extremes over Nigeria. American Journal of Climate Change, 10, 331-352.

https://doi.org/10.4236/ajcc.2021.103016

Received: July 22, 2021

Accepted: September 27, 2021

Published: September 30, 2021

Copyright $\odot 2021$ by author(s) and Scientific Research Publishing Inc. This work is licensed under the Creative Commons Attribution International License (CC BY 4.0).

http://creativecommons.org/licenses/by/4.0/

\begin{abstract}
This study analyzed the spatial distribution and temporal trends of precipitation and its extremes over Nigeria from 1979-2013 using climate indices, in order to assess climatic extremes in the country. Daily precipitation data used in this study were obtained from Nigeria Meteorological Agency (NIMET), Lagos. The study used climate indices developed by the Expert Team on Climate Change Detection (ETCCDI) for assessing extreme precipitation. Sen's slope estimator and Mann-Kendall trend test were employed in data analysis. Results revealed that precipitation and its extremes varied spatially across Nigeria. Significant negative trends were observed in most of the precipitation indices for the period under study. Furthermore, significant downward trends were observed in the CWD (Consecutive Wet Day) while the CDD (Consecutive Dry Day) showed significant upward trends in all the regions. These spatial and temporal changes indicate that Nigeria's climate is trending towards a warmer and drier condition, which could be attributed to global warming-induced climate change; which altered historical rainfall patterns thereby leading to extreme events. The findings of this study have provided useful information in understanding the extreme events that are assumed by the general populace to be normal recurrent events in Nigeria. The results of the analysis of yearly and decadal changes in precipitation totals and extreme values for the last 35 years (1979-2013) suggest the likelihood of severe impacts on water resources, agriculture, and water-sensitive economic activities.
\end{abstract}

\section{Keywords}

Climate Indices, Climate Extreme, Climate Change, Spatial Pattern, Temporal Trends, Nigeria 


\section{Introduction}

It is generally recognized globally that more frequent extreme weather events such as droughts, floods and forest fires, etc. have major environmental impacts, especially in vulnerable developing countries, such as Nigeria (Emily \& Barry, 2014; Kaah, 2017; Yin \& Sun, 2018). This may be due to the fact that some developing countries that have climate-sensitive economic activities are more susceptible to extreme weather events. Also, those developing countries that lack the necessary physical and financial resources along with appropriate institutions to mitigate the adverse effects of climate change are at greater risk (Benson et al., 2017; Nashwan \& Shahid, 2019). Consequently, the increase in magnitude and frequency of extreme events with damaging consequences has attracted the attention of researchers, world leaders, policymakers and others with a vested interest in managing climatic risks and hazards (Gbode et al., 2019, Linden et al., 2019).

Nigeria is one of the countries in West Africa, located between latitude $4^{\circ} \mathrm{N}$ and $14^{\circ} \mathrm{N}$ and longitude $2^{\circ} \mathrm{E}$ and $15^{\circ} \mathrm{E}$. Based on its location, it is endowed with an equatorial climate. Two air masses, namely the dry tropical-continental air mass, and the warm, tropical maritime air mass controlled the climate of Nigeria. The demarcation of these air masses is known as the Inter-Tropical Convergence Zone (ITCZ). The Inter-Tropical Convergence Zone (ITCZ) is the principal weather maker that is responsible for the summer monsoon precipitation in the country. The two seasons observed in the country are rainy and dry seasons. The dry season (November-March) is due to the influence of the dry tropical-continental air mass from the Sahara Desert, while the rainy season (AprilOctober) is due to the warm, tropical maritime air mass from the Atlantic Ocean (Audu \& Okeke, 2018).

The country regularly faces various extreme events such as floods, drought, etc. almost on a yearly basis (Abaje, 2007; Abaje \& Giwa, 2010; Abaje et al., 2013), which is assumed by many as normal recurrent events in Nigeria. This is an indication that the general populace lacks basic knowledge about climate change and the associated extreme events. The impacts of climate change in $\mathrm{Ni}$ geria are mostly observed in climate-dependent sectors. Extreme events such as flooding and drought associated with climate change resulting in low crop yield, food shortage, food scarcity, reduced livestock production, decreased hydroelectric power supply, loss of shelter and road networks, among others (Mbah, 2014). Recently, scientists have projected that Lagos, Africa's most populous city may soon be inhabitable by the end of the $21^{\text {st }}$ century due to flooding resulting from sea levels rise due to climate change (CNN, 2021). Thus, this study attempts to evaluate the spatial distribution and temporal trends of precipitation and its extremes over Nigeria from 1979-2013; in order to assess the impact of climate change in the country. This study will give information about extreme precipitation in Nigeria, which will be useful to policymakers, system planners, resource managers. 
According to (Chhabra \& Haris, 2015), extreme temperature and rainfall values are used as indicators of climate change. Changes in intensity, frequency and duration of these extreme events are measured using climate extreme indices. Accordingly, the spatial distribution and trends of the indices provide insightful information about the magnitude and the rate of change of extreme events.

Moreover, temporal trends of the changes in intensity, frequency, and duration of temperature and precipitation events are indicators of a changing climate. In comparison to temperature and other climatic variables, precipitation also shows a higher degree of variability across a range of space-time scales. Accordingly, precipitation measurement protocols and analysis are more demanding, and consequently require more scrupulous examination (Javanmard et al., 2011; Mohammed et al., 2015; Audu \& Okeke, 2018). Given the importance of rainfall in economic activities and the high degree of vulnerability of Nigeria's population to climate change, there is an urgent need for more insightful analyses of precipitation values, trends and spatial distribution. Also of importance is a comprehension of the chief climate drivers and consequences of climate warming on the spatial and temporal rainfall patterns leading to erratic rainfall, droughts, erosion, landslides and floods.

\section{Rainfall Indices}

A number of extreme temperature and rainfall indices are used to assess extreme weather and climate events (Manton et al., 2001). It is pertinent to note that changes in total and extreme precipitation and temperature indices vary with geographical location (Soltani et al., 2015). However, the ETCCDI has defined 27 climate indices (i.e. 17 indices for temperature and 10 indices for precipitation) which are generally used to investigate extreme temperature and precipitation. These indices have been used by many researchers (Chhabra \& Haris, 2015; Khomsi et al., 2016; Khan et al., 2019). The precipitation indices are shown in Table 1. These indices have been used to study changes in intensity, frequency, and duration of rainfall events due to climate change (Chhabra \& Haris, 2015). According to (Iqbal et al., 2019), global warming-induced climate change affects rainfall pattern.

Many research works on rainfall variability, spatial distribution of rainfall, variation trends of rainfall, extreme rainfall, characteristic of extreme rainfall, climate variability, climate and weather extremes among others have been carried out over the years (Manta, 2010; Emily \& Barry, 2014; Akisanola \& Ogunjobi, 2014; Chhabra \& Haris, 2015; Khomsi et al., 2016; Audu \& Okeke, 2018; Nashwan \& Shahid, 2019; Yin \& Sun, 2018; Iqbal et al., 2019; Khan et al., 2019). Working on trends in climate extremes over Bangladesh, (Khan et al., 2019) observed from precipitation indices a decreasing trend in precipitation. They noted that the annual total precipitation decreased at the rate of about $84 \mathrm{~mm} /$ decade.

The findings of (Iqbal et al., 2019) revealed no significant change in annual precipitation in the Sub-Himalayan region of Pakistan. However, among the rainfall indices considered, noticeable changes were observed in the continuous 
Table 1. Extreme precipitation indices developed by ETCCDI (Zhang \& Yang, 2017).

\begin{tabular}{|c|c|c|c|}
\hline Index & Long name & Definition & Units \\
\hline RX1 day & Max 1-day precipitation amount & Monthly maximum 1-day precipitation & $\mathrm{mm}$ \\
\hline RX5 day & Max 5-day precipitation amount & Monthly maximum consecutive 5 -day precipitation & $\mathrm{mm}$ \\
\hline SDII & Simple daily intensity index & $\begin{array}{l}\text { Annual total precipitation divided by number of wet days } \\
\text { (defined as } \mathrm{PRCP} \geq 1.0 \mathrm{~mm} \text { ) in the year }\end{array}$ & $\mathrm{mmd}^{-1}$ \\
\hline $\mathrm{R} 10$ & Number of heavy precipitation days & Annual count of days when PRCP $\geq 10 \mathrm{~mm}$ & Days \\
\hline $\mathrm{R} 20$ & Number of very heavy precipitation days & Annual count of days when $\mathrm{PRCP} \geq 20 \mathrm{~mm}$ & Days \\
\hline CDD & Consecutive dry days & Maximum number of consecutive days with $\mathrm{PRCP}<1 \mathrm{~mm}$ & Days \\
\hline CWD & Consecutive wet days & Maximum number of consecutive days with $\mathrm{PRCP} \geq 1 \mathrm{~mm}$ & Days \\
\hline R95p & Very wet days & Annual total PRCP when PRCP > 95th percentile & $\mathrm{mm}$ \\
\hline R99p & Extremely wet days & Annual total PRCP when PRCP > 99th percentile & $\mathrm{mm}$ \\
\hline PRCPTOT & Annual total wet-day precipitation & Annual total PRCP in wet days (PRCP $\geq 1 \mathrm{~mm}$ ) & $\mathrm{mm}$ \\
\hline
\end{tabular}

wet and dry days. According to (Emily \& Barry, 2014), the impacts of extreme weather and climate events are noticeably increasing nationwide and are more pronounced now than ever before. Hence, there is a need for more research in this area particularly in Nigeria with little or no research about extreme events in recent times.

\section{Data and the Methodology}

1) Data of daily precipitation for 35 years from 1979 to 2013 for 10 meteorological stations, located across the country were used for spatial distribution analysis of precipitation and its extreme events over Nigeria (Table 2). These stations were chosen due to consistence and availability of daily data for the period under study.

2) Subsequently, six stations representing the six vegetation zones of Nigeria were selected to assess temporal trends of precipitation extremes.

3) The daily precipitation data was subjected to strict quality checks using RClimdex 1.1 Software developed by the ETCCDI. This is available freely at the ETCCDI website http://etccdi.pacificclimate.org/indices.shtml (Zhang \& Yang, 2017). Erroneous data, such as negative precipitation, and missing data were replaced with -99.9 , which is recognized by RClimDex. In order to avoid erroneous computation, homogeneity tests were also performed employing RHtests version 4 software package on the whole data set.

4) Climate indices developed by the ETCCDI for computing extreme precipitation were adopted (Zhang \& Yang, 2017).

5) Changes in mean yearly precipitation indices were analysed using Sen's slope method which is a non-parametric estimator of the change in time series. Detail on Sen's slope method was discussed by (Nashwan \& Shahid, 2019).

6) The significance of the trends of mean yearly precipitation indices was analysed employing Mann-Kendall trend test at 0.05 significant level. See (Iqbal et al., 2019) for detail on Mann-Kendall trend test. 
Table 2. Meteorological stations and their geographical location.

\begin{tabular}{ccccc}
\hline Region & Station & Code & Longitude & Latitude \\
\hline Northwest & ${ }^{*}$ Sokoto & SOK & 5.3125 & 13.2697 \\
Northeast & ${ }^{*}$ Maiduguri & MAI & 13.125 & 12.0208 \\
Northeast & Bauchi & BAU & 10.3125 & 10.7719 \\
Northeast & Kaduna & KAD & 7.1875 & 10.4597 \\
North Central & ${ }^{*}$ Ilorin & ILO & 4.6875 & 8.5862 \\
North Central & Makurdi & MAK & 8.4375 & 7.6496 \\
Southwest & ${ }^{*}$ Ikeja & IKE & 3.4375 & 6.7129 \\
Southeast & ${ }^{*}$ Enugu & ENU & 7.8125 & 6.4006 \\
South-south & ${ }^{*}$ Port Harcourt & P/H & 7.1875 & 4.8395 \\
South-south & Benin & BEN & 5.625 & 6.4006 \\
\hline
\end{tabular}

*Stations used for temporal trend analysis.

7) The software R was employed in the analysis.

8) Finally, Inverse Distance Weighted (IDM) technique for interpolation was used in estimating the spatial distribution of precipitation and its extremes across Nigeria from the overall averages; employing ArcGIS 10.3 software. The IDW method employed gives high spatial resolution, accuracy, and precision, however the output is limited to the range of the values used for interpolation (Watson \& Philip, 1985).

\section{Analysis and Results}

\subsection{Spatial Distribution of Precipitation and Its Extreme}

The spatial distribution of Max 1-day precipitation amount (RX1) shows that RX1 varies across the country (Figure 1(a)). Low value of (79.81 - 88.96 $\mathrm{mm} /$ year) was observed at the extreme northwestern and eastern regions in stations such as Sokoto and Maiduguri, while high value (109.13 - $119.37 \mathrm{~mm} /$ year) was recorded in stations such as Jos and Makurdi in the north-central region. The Max 5-day precipitation amount (RX5) also showed similar spatial pattern like RX1 (Figure 1(b)). The minimum and maximum values of RX5 are 130.52 145.33 and $174.71-191.44 \mathrm{~mm}$ /year.

On the other hand, number of heavy precipitation days (R10) and number of very heavy precipitation days (R20) decreased from the coastal area to the northeastern and western areas (Figure 2(c) \& Figure 2(d)). The minimum values for R10 and R20 for the period under study ranges from 14.62 - 30.78 and 7.06 $10.60 \mathrm{~mm} /$ year, while the maximum values range from $89.29-119.16$ and 19.24.65 mm/year respectively.

Similarly, the very wet days (R95p) and extremely wet days (R99p) decreased from the coastal region to the northern region. The R95p recorded the minimum and maximum values of $185.02-277.68$ and $507.69-606.97 \mathrm{~mm} /$ year, while the R99p recorded 56.92 - 94.75 and $183.46-232.29 \mathrm{~mm}$ /year as the minimum and 


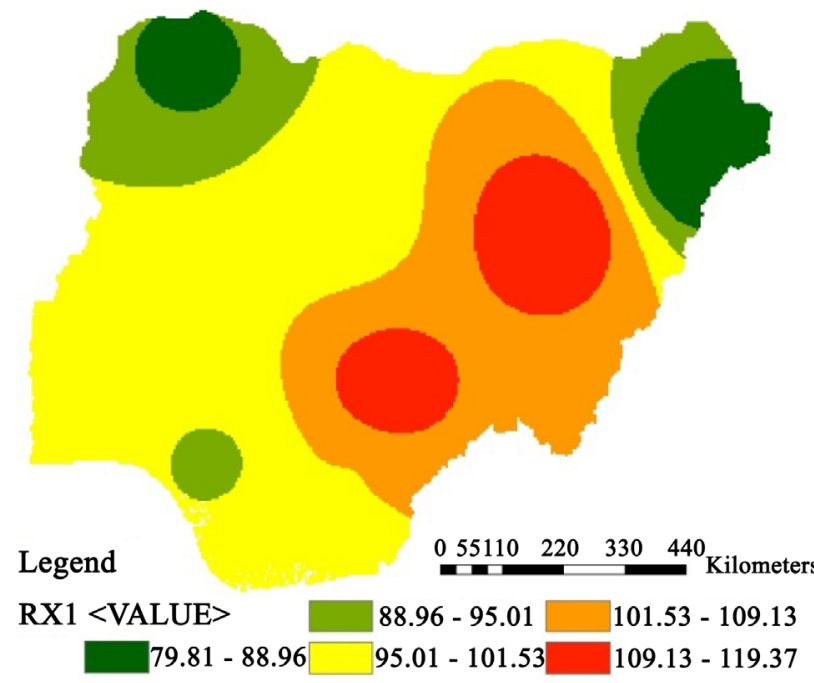

(a)

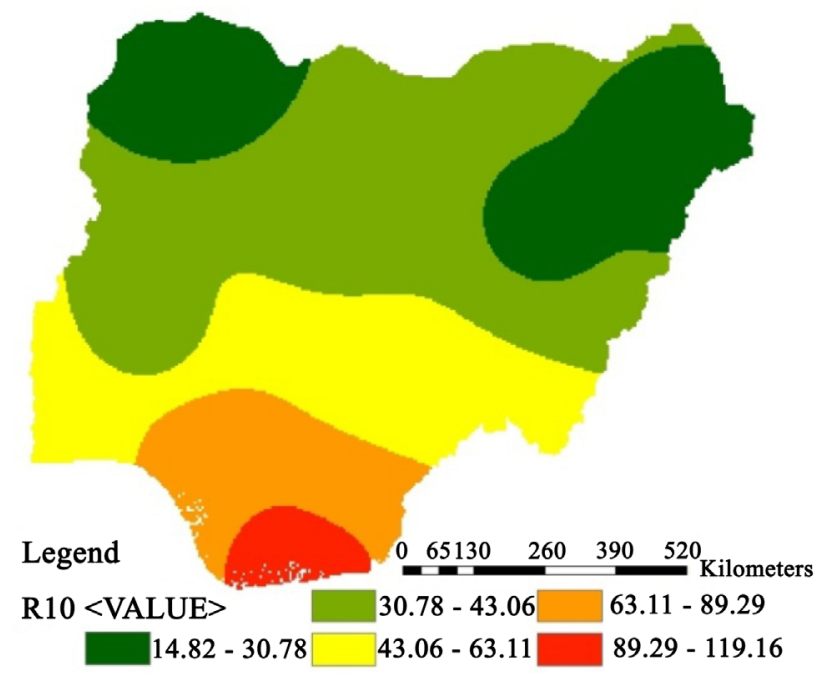

(c)

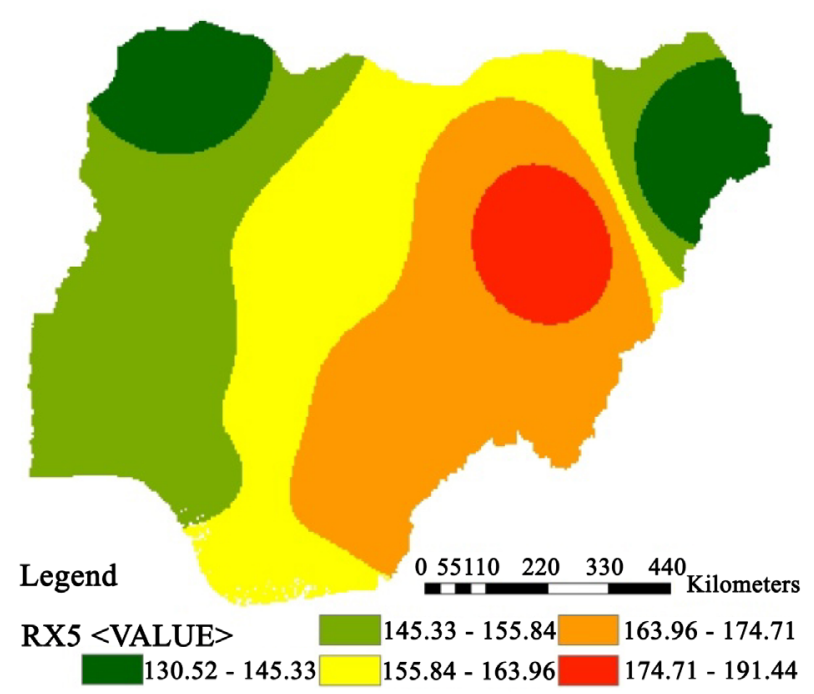

(b)

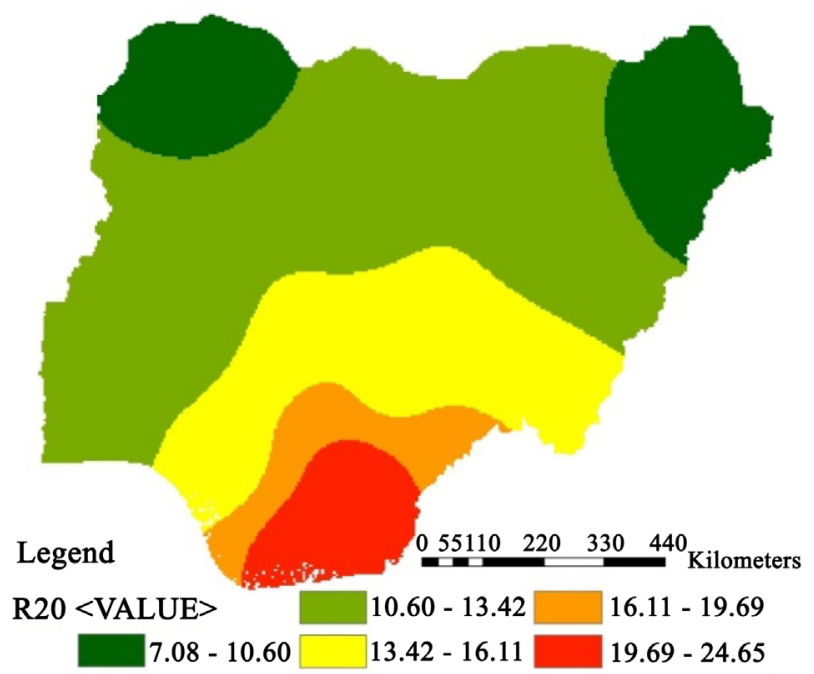

(d)

Figure 1. Spatial pattern of overall averages of annual (a) RX1 (b) RX5 (c) R10 and (d) R20 across Nigeria (1979-2013).

maximum values respectively. The annual total wet-day precipitation (PRCPTOT) also decreased steadily from the coastal region to the northern region. It ranges from 561.8 - 970.2 and 2464.6 - $3102.2 \mathrm{~mm}$ /year (Figure 2(c)).

It is interesting to note that among the indices considered so far, apart from RX1 and RX5, every other index decreased from the coastal region to the northern region. This depicts that RX1 and RX5 have different spatial distributions across the country.

Consequently, the results imply that the variations of the precipitation indices may be the possible explanation for the erratic rainfall, desertification, erosion, land sliding and flooding experienced across the country. It could be observed from Figure 2(d) that simple daily intensity index (SDII) was low in the southwestern region (8.49 - $9.80 \mathrm{~mm}$ /year) but high in stations such as Bauchi in the north (11.79 - $12.84 \mathrm{~mm} /$ year). 


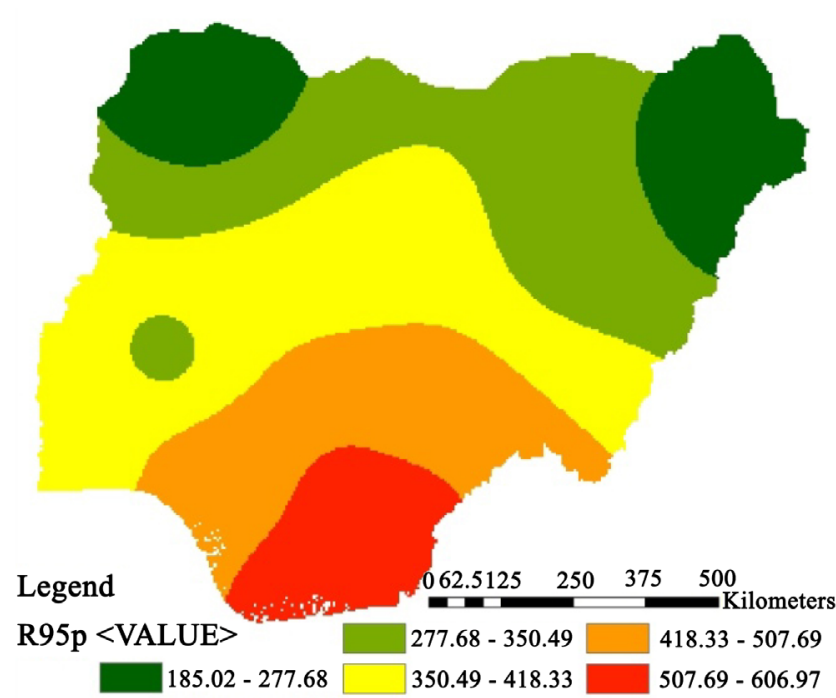

(a)

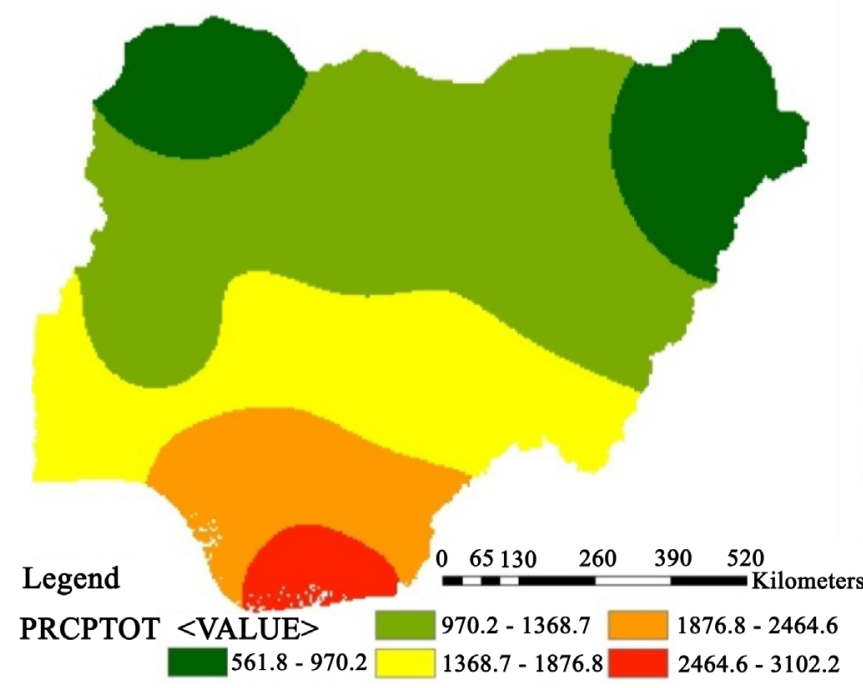

(c)

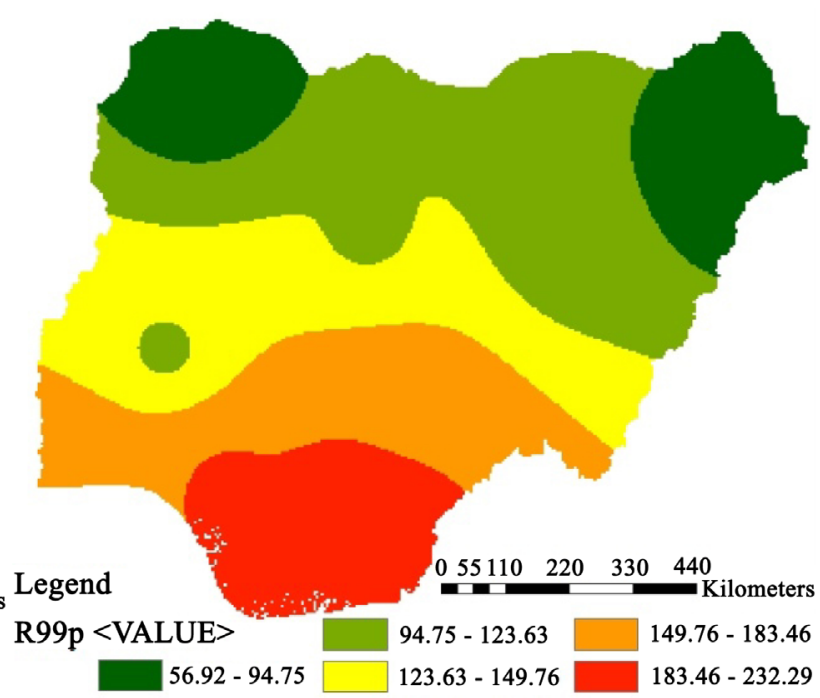

(b)

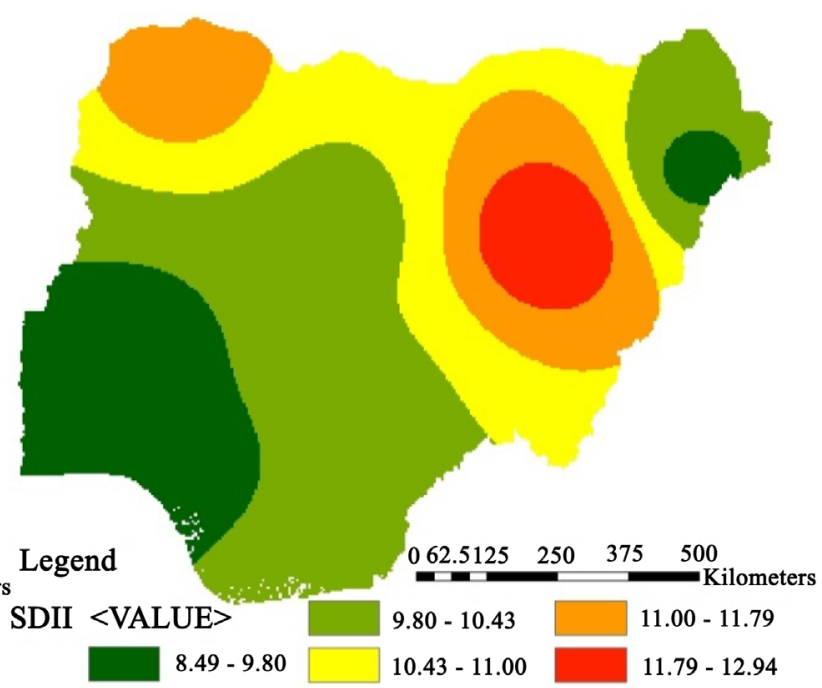

(d)

Figure 2. Spatial pattern of overall averages of annual (a) R95p (b) R99p (c) PRCPTOT and (d) SDII across Nigeria (1979-2013).

From the spatial distribution of consecutive wet days (CWD) shown in Figure 3(a), low CWD were observed in the northeastern and western regions 7.20 17.74 days) but high in the coastal region (65.91 - 96.85 days). In contrast, from Figure $3(\mathrm{~b})$, the consecutive dry days (CDD) was low in the coastal region (15.43 - 62.89 days) but high in the northwestern region (17.63 - 217.14 days).

\subsection{Temporal Trend of Precipitation and Its Extreme}

From Figure 4(ai) \& Figure 4(bi), non-significant positive trends were observed for RX1 with an annual increase of $0.102,0.481,0.082$, and $0.575 \mathrm{~mm} /$ year in Sokoto, Ilorin, Ikeja and Port Harcourt respectively. Non-significant negative trends were however observed in Maiduguri and Enugu with an annual decrease of -0.39 and -0.483 respectively (Table 3 ). 


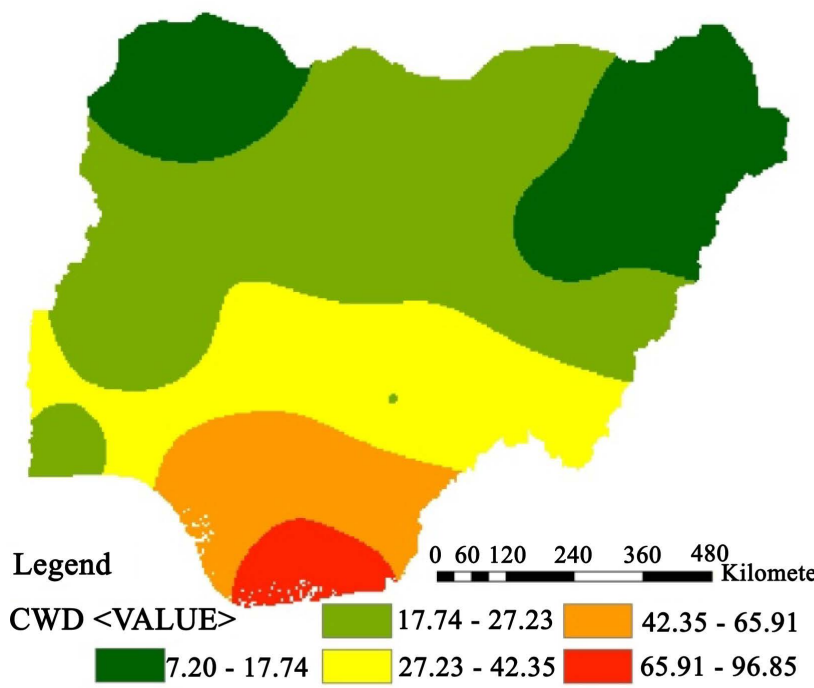

(a)

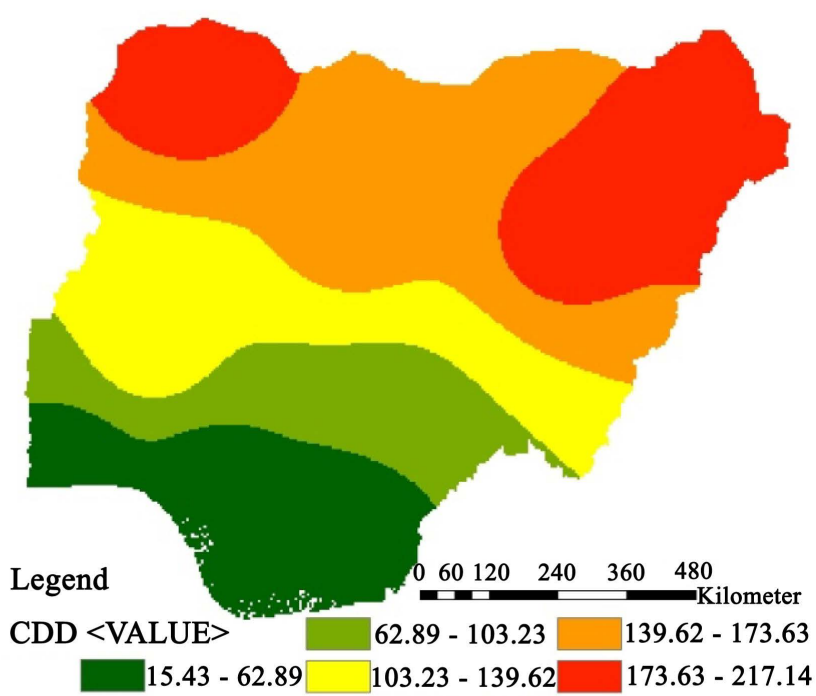

(b)

Figure 3. Spatial pattern of overall averages of annual (a) CWD and (b) CDD across Nigeria (1979-2013).

Table 3. Trends of extreme precipitation indices in selected cities over Nigeria from 1979-2013.

\begin{tabular}{|c|c|c|c|c|c|c|c|c|c|c|c|c|}
\hline \multirow{2}{*}{$\begin{array}{l}\text { Indices } \\
\text { RX1 day }\end{array}$} & \multicolumn{2}{|c|}{$\begin{array}{c}\text { Sokoto } \\
\text { Trends P-value }\end{array}$} & \multicolumn{2}{|c|}{$\begin{array}{c}\text { Maiduguri } \\
\text { Trends P-value }\end{array}$} & \multicolumn{2}{|c|}{$\begin{array}{c}\text { Ilorin } \\
\text { Trends P-value }\end{array}$} & \multicolumn{2}{|c|}{$\begin{array}{c}\text { Ikeja Trends } \\
\text { P-value }\end{array}$} & \multicolumn{2}{|c|}{$\begin{array}{c}\text { Enugu Trends } \\
\text { P-value }\end{array}$} & \multicolumn{2}{|c|}{$\begin{array}{l}\text { Port Harcourt } \\
\text { Trends P-value }\end{array}$} \\
\hline & 0.102 & 0.888 & -0.39 & 0.541 & 0.481 & 0.475 & 0.082 & 0.902 & -0.483 & 0.369 & 0.575 & 0.297 \\
\hline RX5 day & -0.743 & 0.499 & -1.544 & 0.147 & 0.734 & 0.388 & 0.643 & 0.416 & -0.808 & 0.311 & 0.490 & 0.427 \\
\hline SDII & -0.093 & 0.180 & -0.029 & 0.582 & 0.019 & 0.531 & -0.007 & 0.688 & -0.002 & 0.921 & -0.026 & 0.114 \\
\hline R10 & -0.546 & 0.000 & -0.077 & 0.539 & -0.155 & 0.271 & -0.234 & 0.233 & -0.094 & 0.655 & -0.939 & 0.012 \\
\hline R20 & -0.287 & 0.001 & -0.030 & 0.695 & -0.096 & 0.162 & -0.021 & 0.721 & -0.110 & 0.341 & -0.225 & 0.035 \\
\hline CDD & 1.715 & 0.017 & 0.900 & 0.076 & 1.766 & 0.001 & 0.076 & 0.791 & 0.410 & 0.189 & 0.139 & 0.409 \\
\hline CWD & -0.224 & 0.024 & -0.009 & 0.901 & -0.139 & 0.351 & -0.239 & 0.200 & -0.034 & 0.919 & -0.198 & 0.736 \\
\hline R99P & 0.294 & 0.830 & -1.638 & 0.227 & -0.525 & 0.795 & 0.765 & 0.745 & -3.140 & 0.243 & 1.685 & 0.504 \\
\hline PRCPTOT & -18.495 & 0.001 & -2.274 & 0.606 & -10.277 & 0.019 & -2.791 & 0.593 & -11.525 & 0.060 & -15.13 & 0.017 \\
\hline
\end{tabular}

It could be observed from Figure 4(aii) \& Figure 4(bii) that RX5 showed negative trends in Sokoto, Maiduguri and Enugu with an annual decrease of $-0.743,-1.544$ and $-0.808 \mathrm{~mm} /$ year, while positive trends were observed in Ilorin, Ikeja and Port Harcourt with an annual increase of $0.734,0.643$, and 0.490 $\mathrm{mm} /$ year respectively. These trends are not significant at $p<0.05$ (Table 3 ). This implies that for the last 35 years, RX1 has changed by $3.57,-13.65,16.835,2.87$, -16.905 , and $20.125 \mathrm{~mm}$ while RX5 have changed by $-26.005,-54.04,25.69$, $22.505,-28.28$, and $17.15 \mathrm{~mm}$.

From Figure 5(ai) \& Figure 5(bi), negative trends were observed in R10 and R20 in all the study areas. Similarly, R95p also showed negative trends (Figure 6(ai) \& Figure 6(bi)). These trends are not significant at $p<0.05$ (Table 3). 


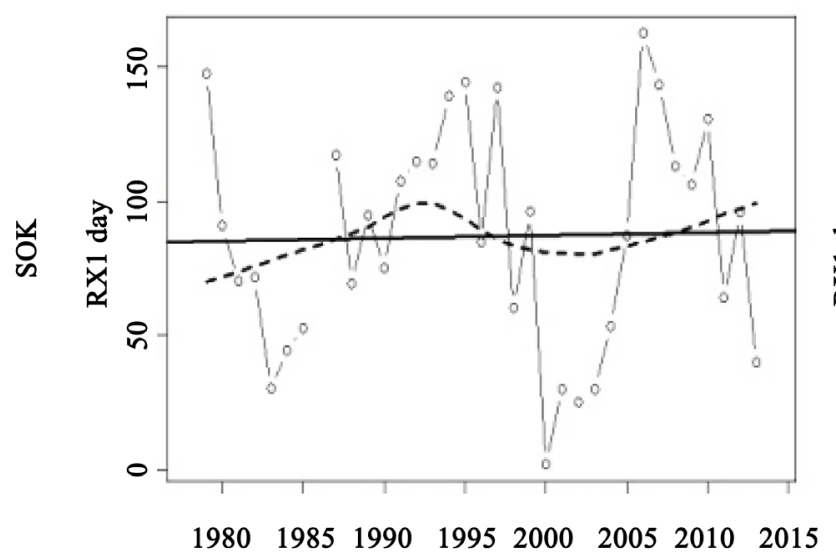

Year

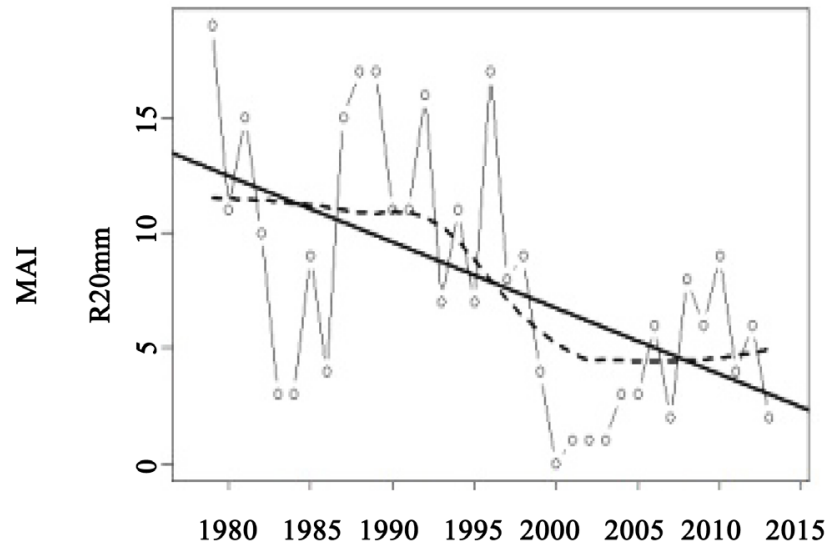

Year

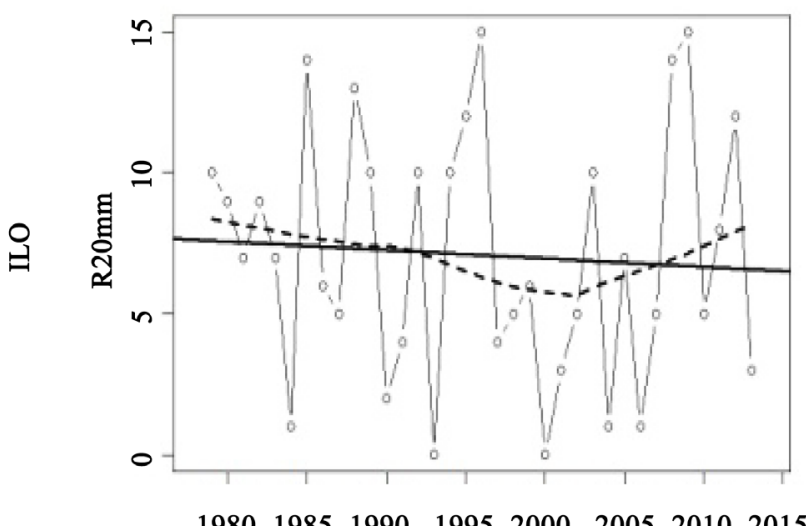

Year

(i) RX1

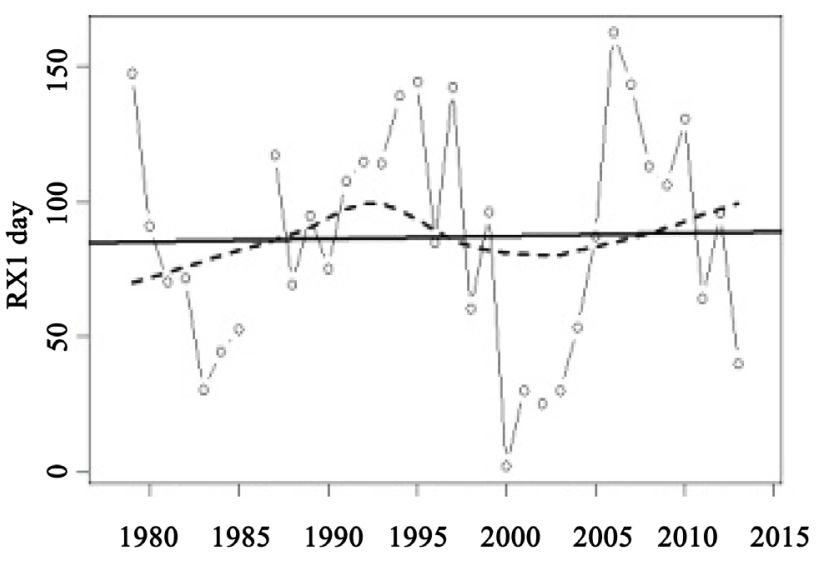

Year
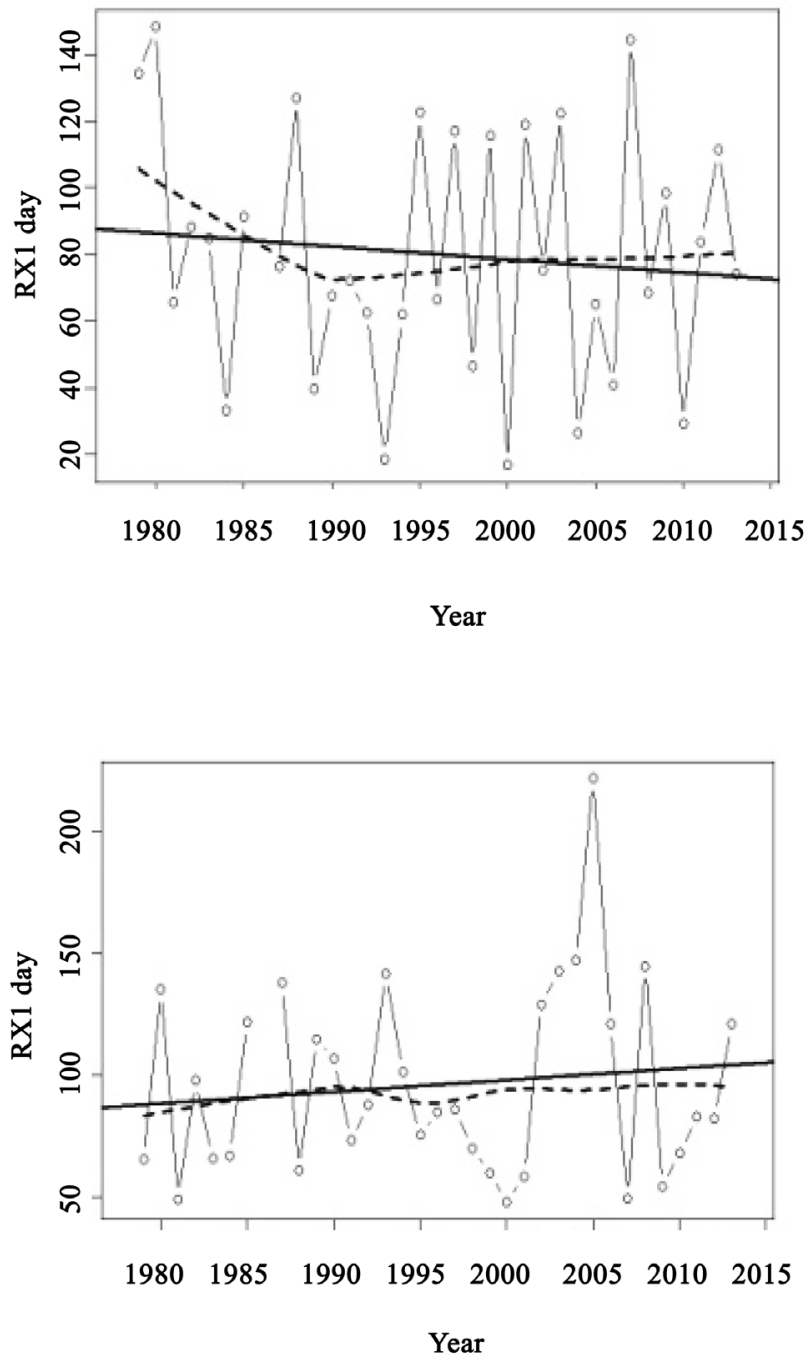

(ii) RX5

(a) 

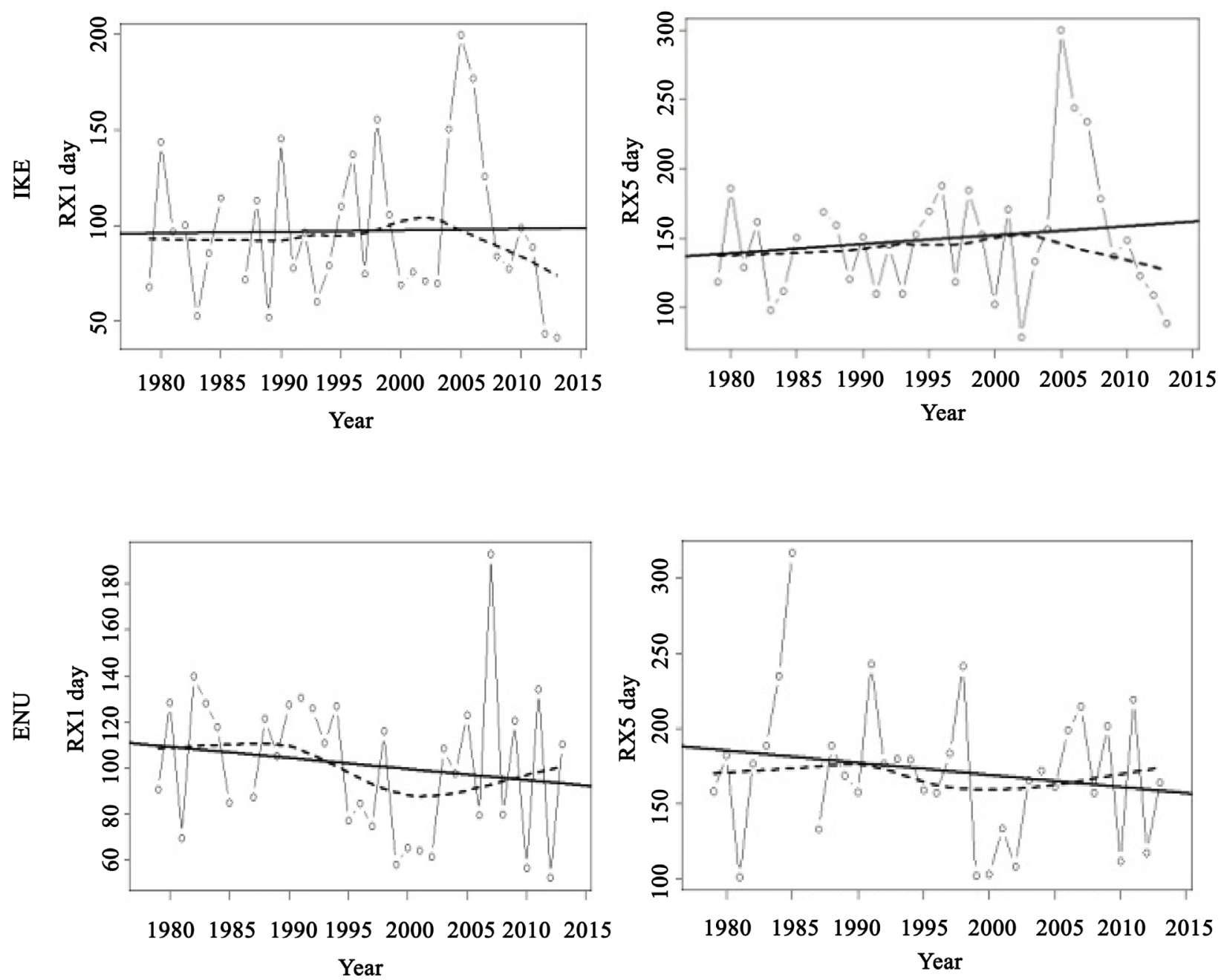

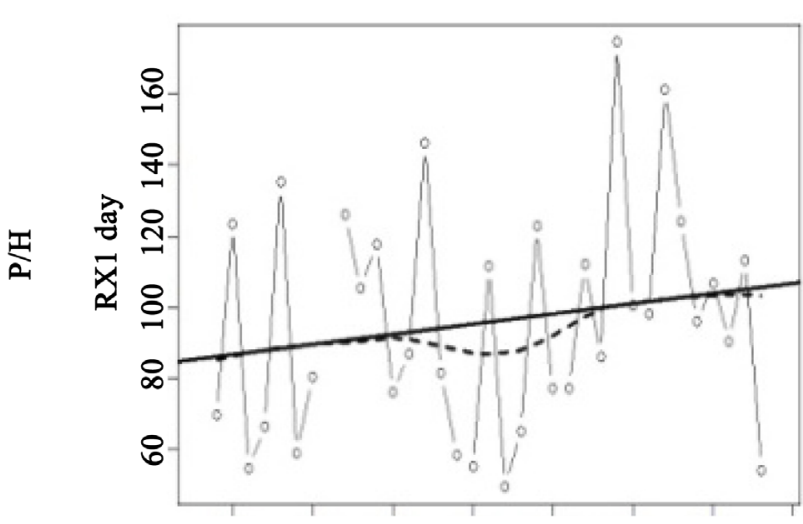

19801985199019952000200520102015 Year

(i) $\mathrm{RX} 1$

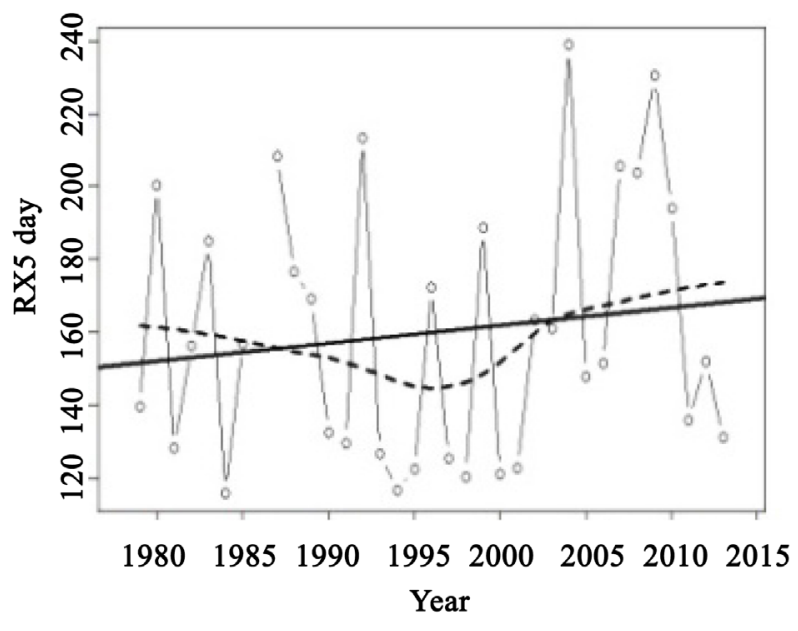

(ii) $\mathrm{RX5}$

(b)

Figure 4. (a): Temporal trends of yearly mean (i) RX1 and (ii) RX5 for selected stations in Nigeria (1979-2013); (b): Temporal trends of yearly mean (i) RX1 and (ii) RX5 for selected stations in Nigeria (1979-2013). 

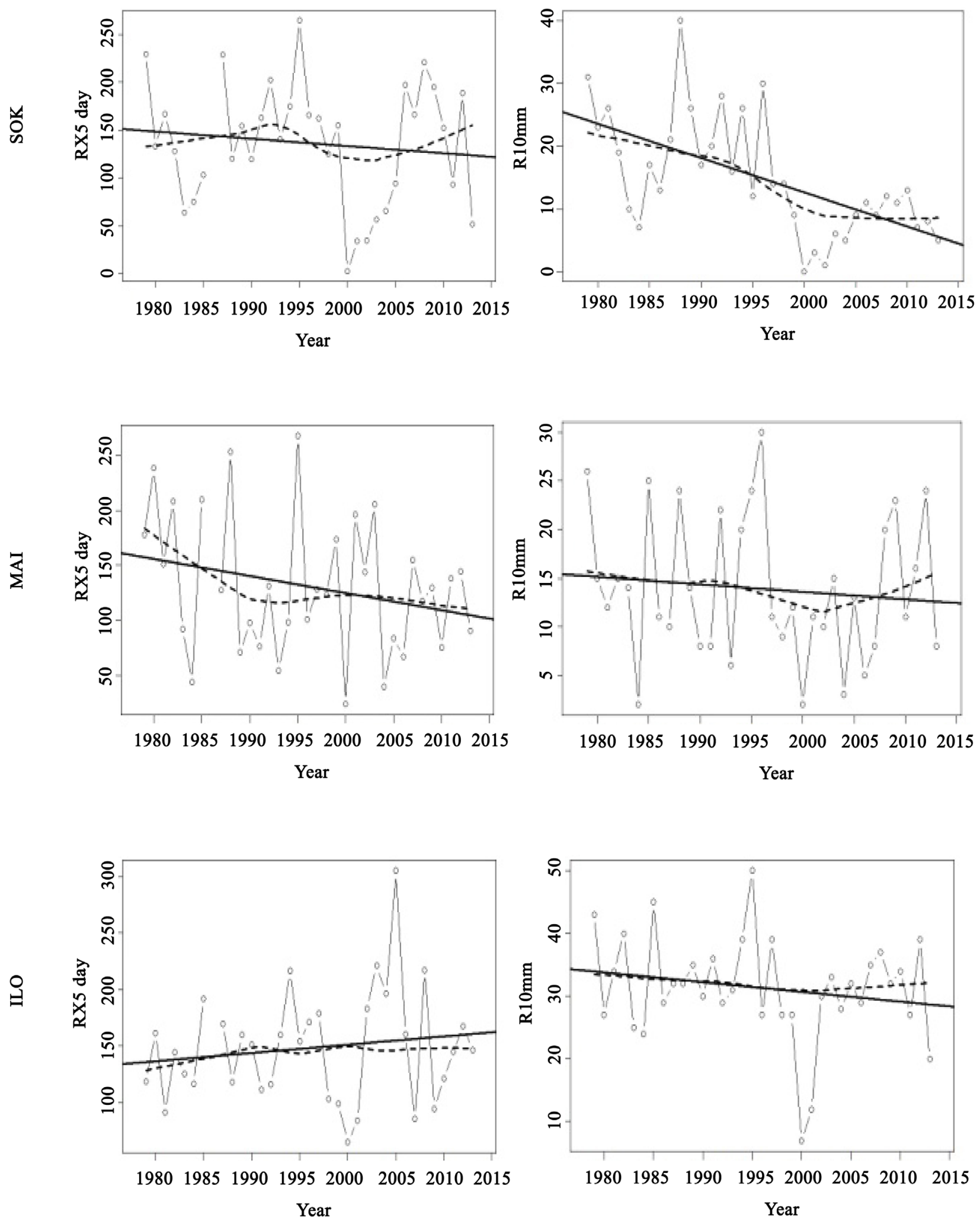

(i) R10

(ii) R20

(a) 


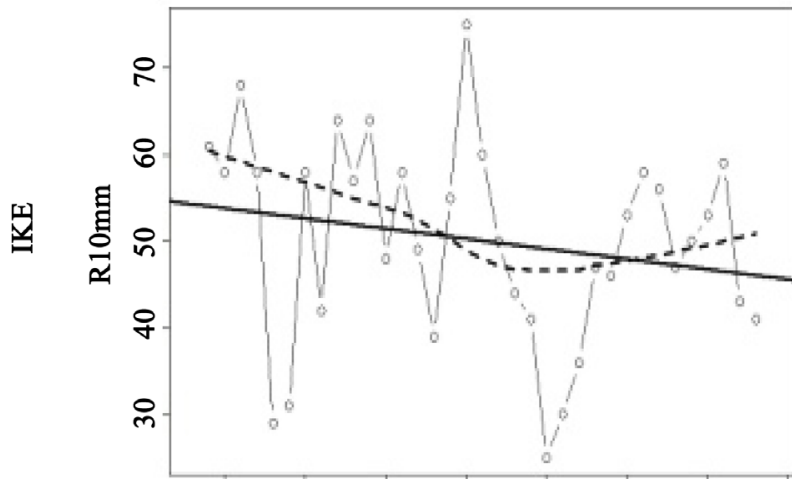

19801985199019952000200520102015

Year

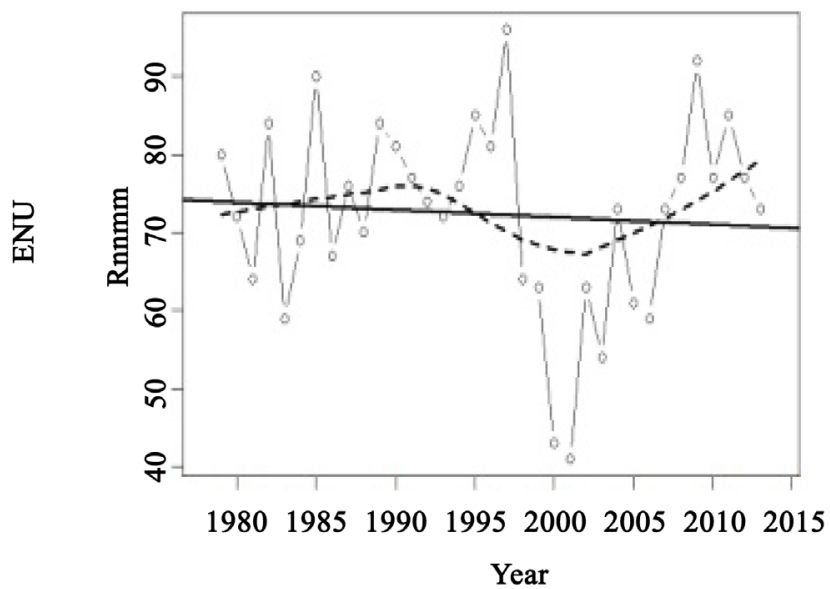

Year

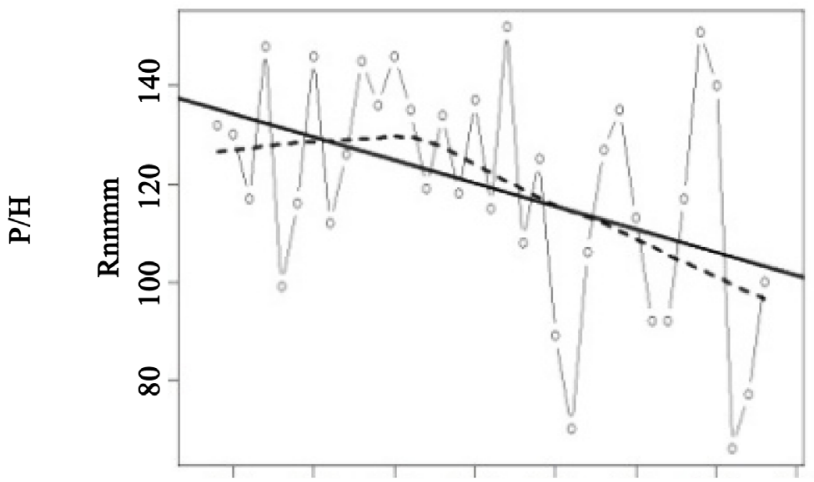

$\begin{array}{llllllll}1980 & 1985 & 1990 & 1995 & 2000 & 2005 & 2010 & 2015\end{array}$

Year

(i) R10
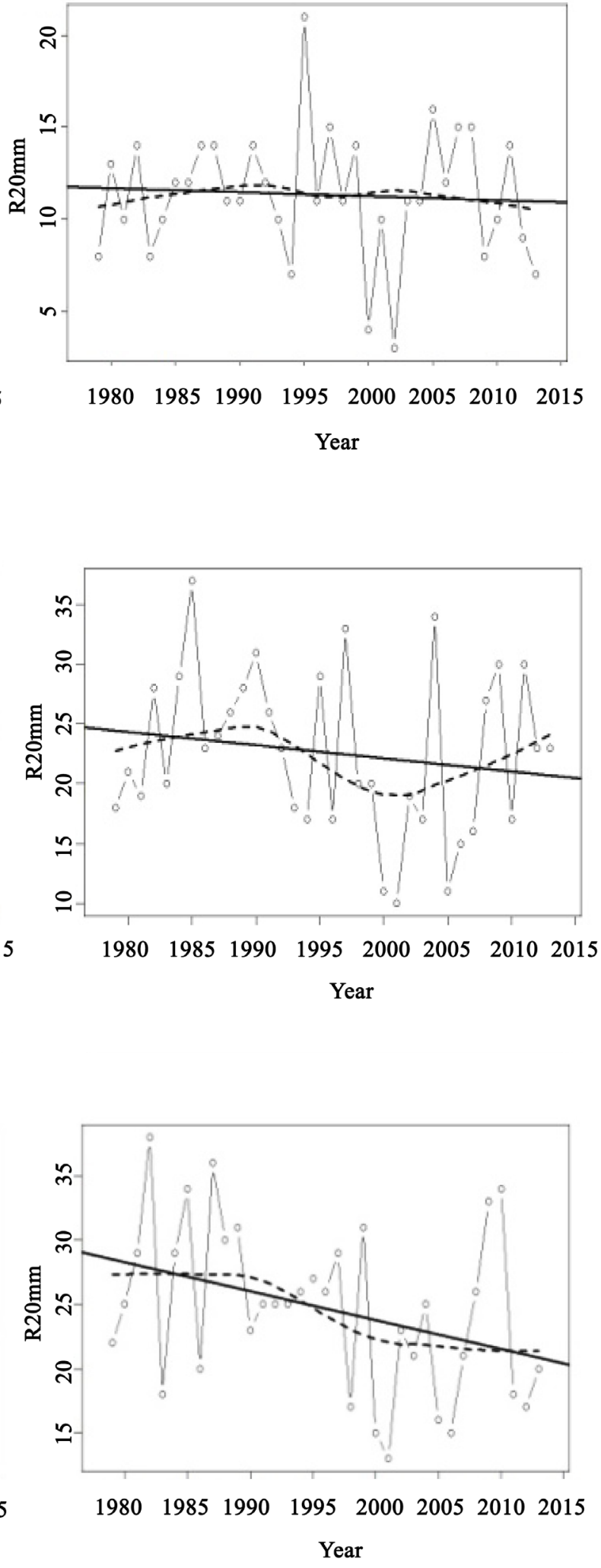

(ii) R20

(b)

Figure 5. (a): Temporal trends of yearly mean (i) R10 and (ii) R20 for selected stations in Nigeria (1979-2013); (b): Temporal trends of yearly mean (i) R10 and (ii) R20 for selected stations in Nigeria (1979-2013). 

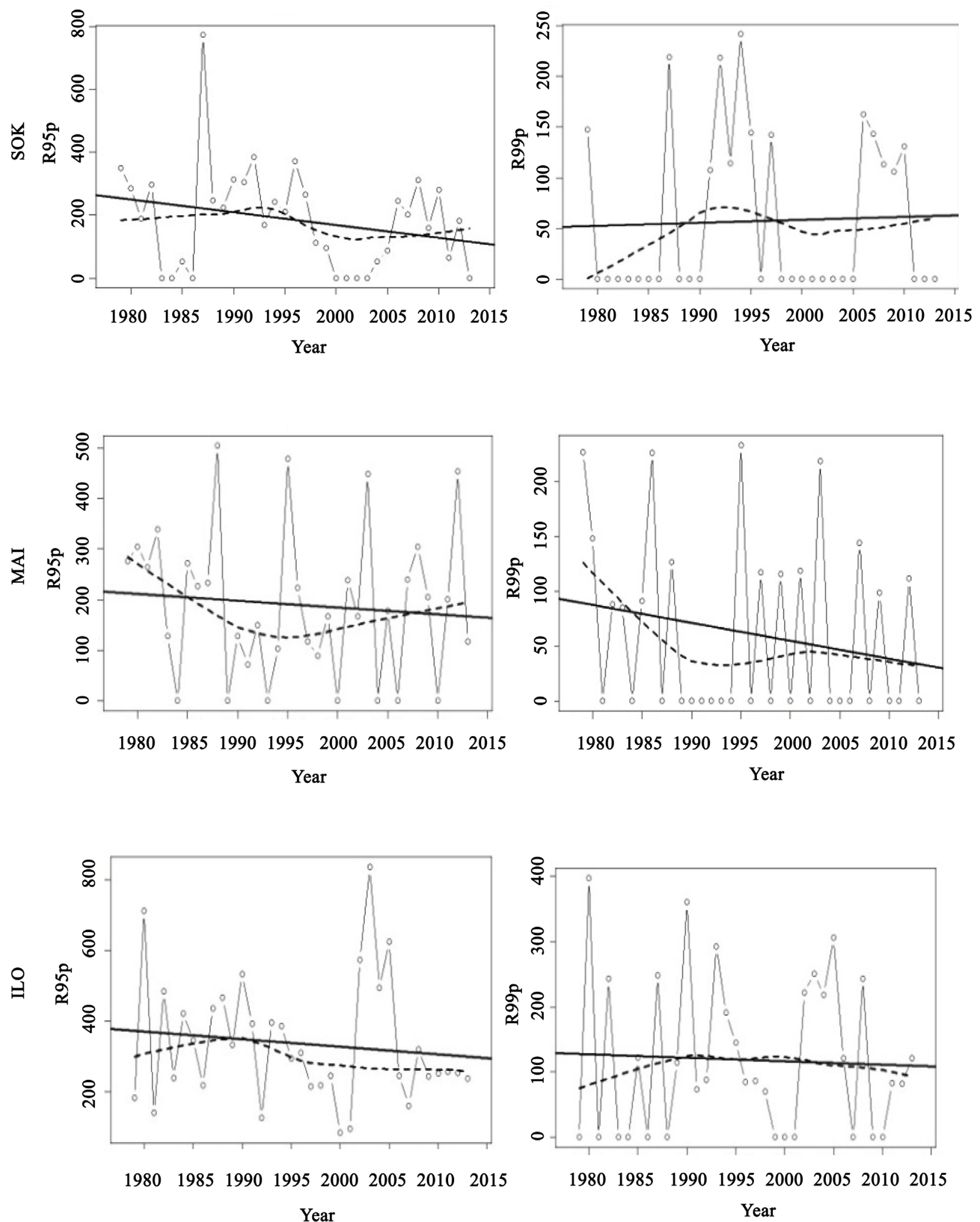

(i) R95p

(ii) R99p

(a) 


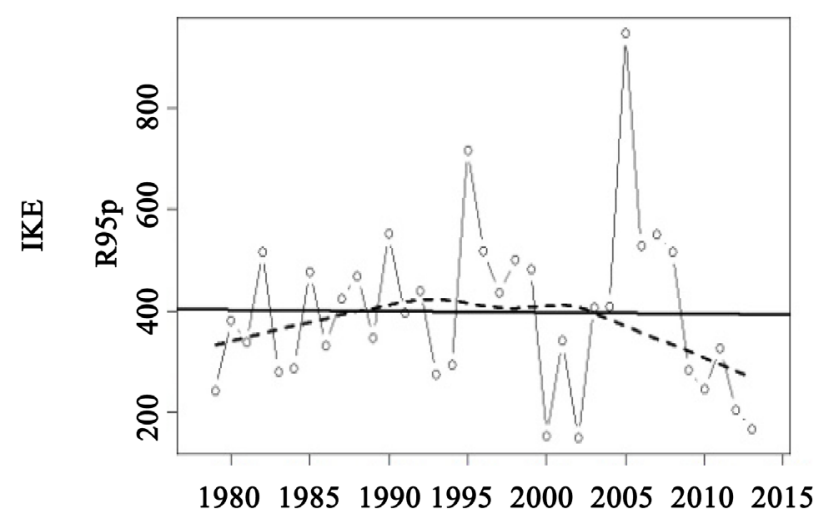

Year

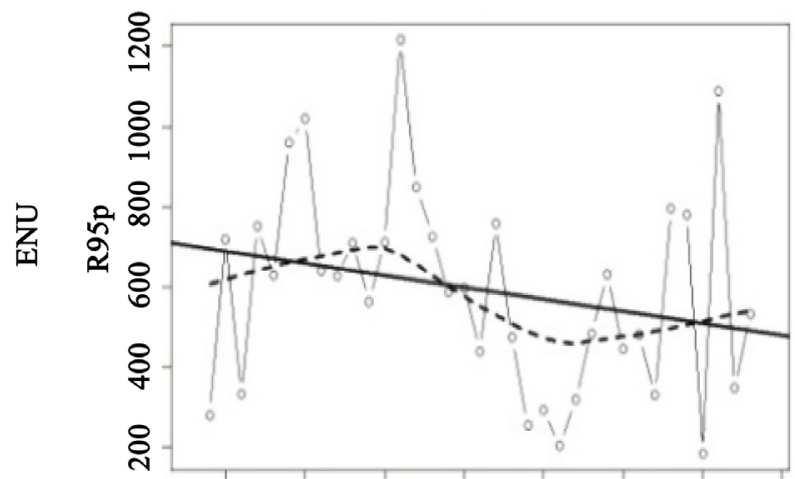

19801985199019952000200520102015

Year

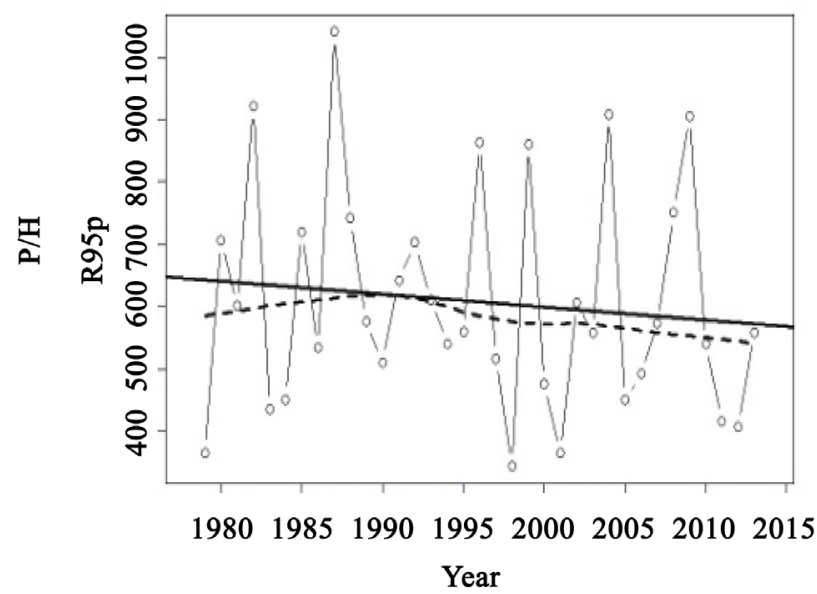

(i) $\mathrm{R} 95 \mathrm{p}$
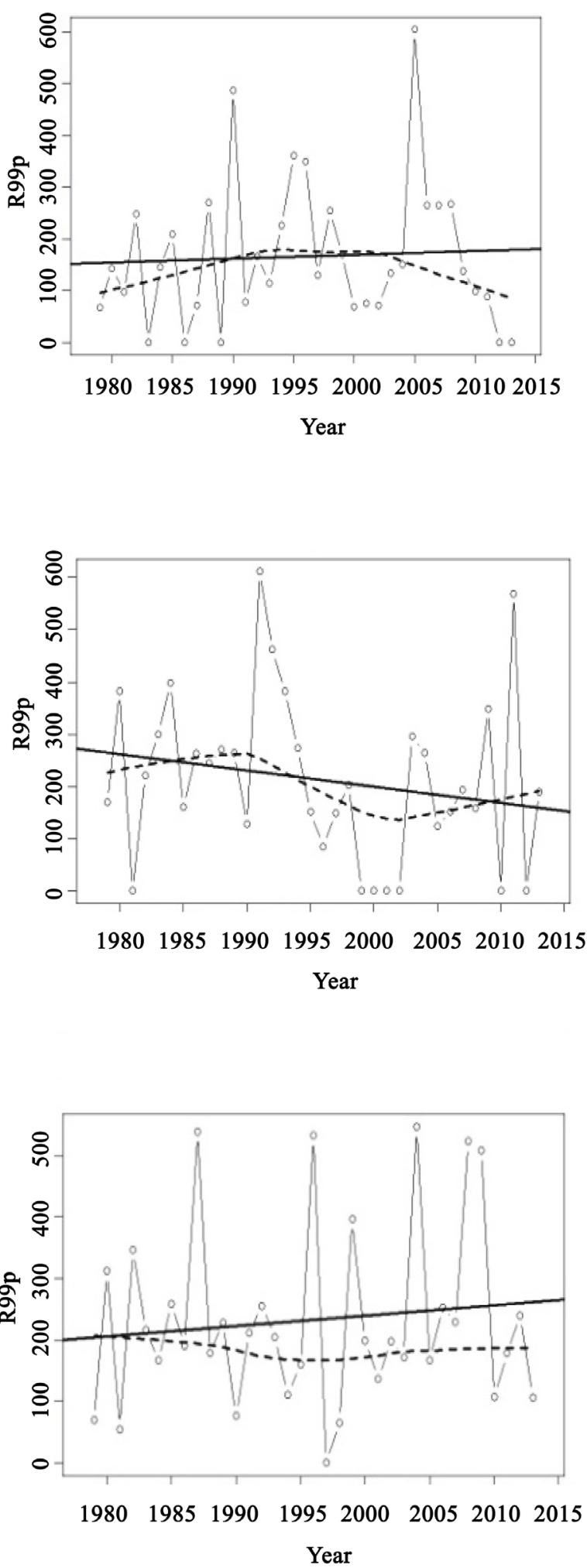

(ii) R99p

(b)

Figure 6. (a): Temporal trends of yearly mean (i) R95p and (ii) R99p for selected stations in Nigeria (1979-2013); (b): Temporal trends of yearly mean (i) R95p and (ii) R99p for selected stations in Nigeria (1979-2013). 
This depicts that R10, R20, and R95p generally decreased in all the zones in the study period.

The R99p showed non-significant positive trends in Sokoto, Ikeja, and Port Harcourt at the rate of $0.29,0.76$, and $1.68 \mathrm{~mm} /$ year (Table 3). Non-significant negative trends were observed in Maiduguri, Ilorin, and Enugu (Figure 6(aii) \& Figure 6(bii)) with an annual decrease of $-1.63,-0.52$, and $-3.14 \mathrm{~mm} /$ year (Table 3). This implies that for the last 35 years, R99p has changed by 10.29, $-57.33,-18.37,26.77,-109.9$, and $58.97 \mathrm{~mm}$ in Sokoto, Maiduguri, Ilorin, Ikeja, Enugu, and Port Harcourt respectively.

Negative trends were observed in the daily total precipitation (PRCPTOT) in all the study areas (Figure 7(ai) \& Figure 7(bi)). This depicts that PRCPTOT decreased in the period under study. It is worthy of note that PRCPTOT decreased at the rate of $-184.95,-22.74,-102.77,-27.91,-115.25$ and -151.30 $\mathrm{mm} /$ decade in Sokoto, Maiduguri, Ilorin, Ikeja, Enugu, and Port Harcourt respectively. Several researchers have reported decreasing trends for PRCPTOT. (Khan et al., 2019) observed decreasing trend in precipitation from their study. They noted that the annual total precipitation decreased at the rate of about 84 $\mathrm{mm} /$ decade.

Considering the stations representing each of the vegetation zones of Nigeria used in this study (Table 3), it is interesting to note that RX1 and R99P show increasing positive trends in Sokoto (North West). RX1 and RX5 show an increasing positive trend in Ilorin (North Central). Increasing positive trends were observed in RX1, RX5 and R99P in Ikeja (Southwest) and Port Harcourt (coastal area). However, decreasing trends were observed in Maiduguri (North East) and Enugu (South East). This depicts that the increasing trends in the RX1, RX5 and R99P could be the major cause of landslide and flood in most regions of Nigeria. According to (Iqbal et al., 2019) RX1 often leads to sudden occurrence of a large amount of rainfall and such rainfall often results in land sliding and flooding.

It is pertinent to note that the increasing trends observed in the precipitation indices in some stations could be the possible explanation for increasing landslide, erosion and flooding in such regions. On the other hand, decreasing trends of precipitation indices could be the possible explanation for the erratic rainfall, drought, and desertification in such regions. This is because these indices contribute to annual and seasonal changes in precipitation (Gajić-Čapka et al., 2015).

From Figure 7(aii) \& Figure 7(bii), non-significant negative trends were observed for simple daily intensity index (SDII) in all the study areas except Ilorin, having non-significant positive trends. This depicts a decrease in the average rainfall amount that falls on a wet day in the stations except Ilorin. According to (Chhabra \& Haris, 2015; Khan et al., 2019), the SDII is the measurement of the average rainfall amount that falls on a wet day in a given year.

Similarly, negative trends were observed in consecutive wet days (CWD) in all the study areas (Figure 8(ai) \& Figure 8(bi)). In contrast, positive trends were observed in all the study areas (Figure 8 (aii) \& Figure 8(bii)). This depicts that 

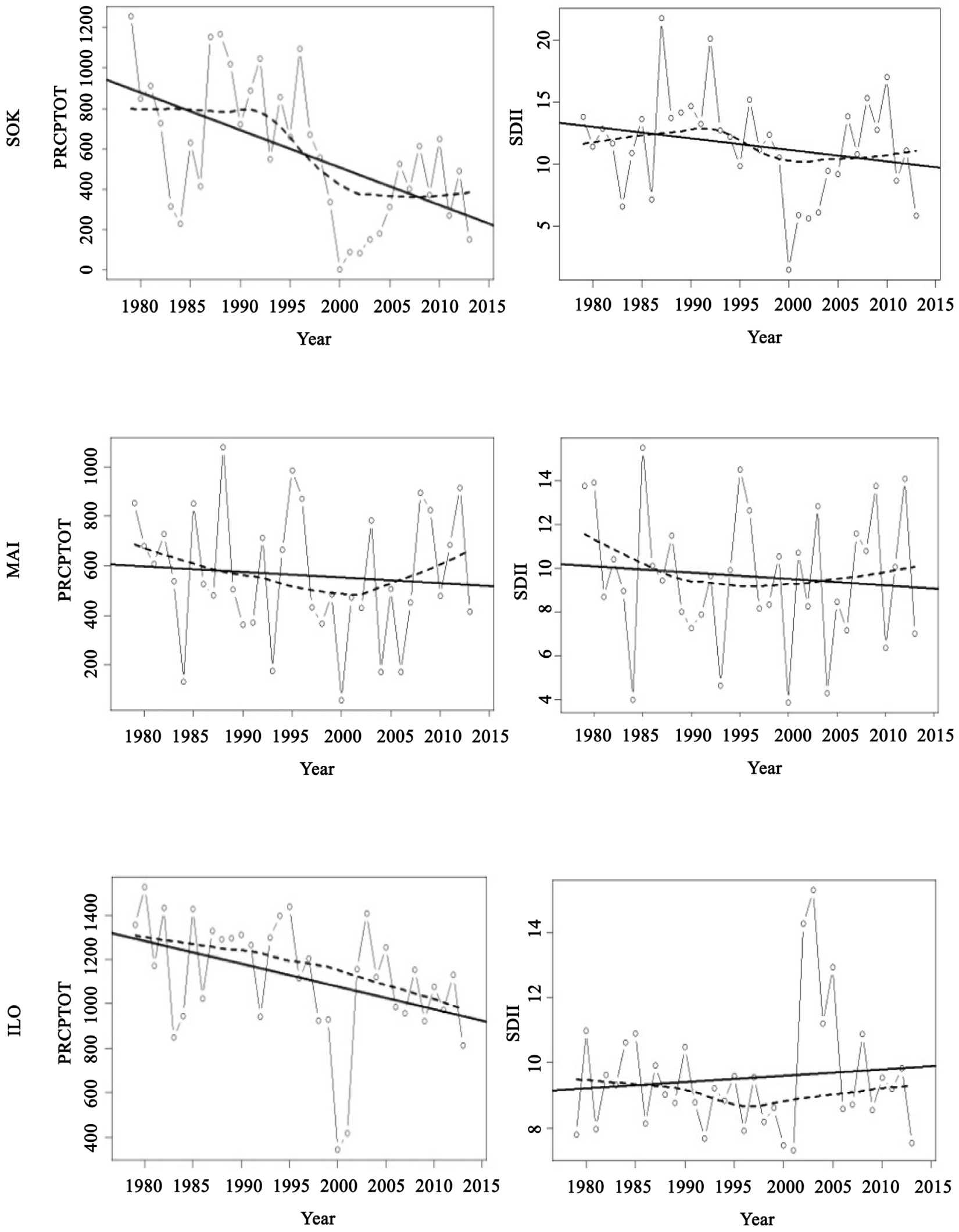

(i) PRCPTOT

(ii) SDII

(a) 

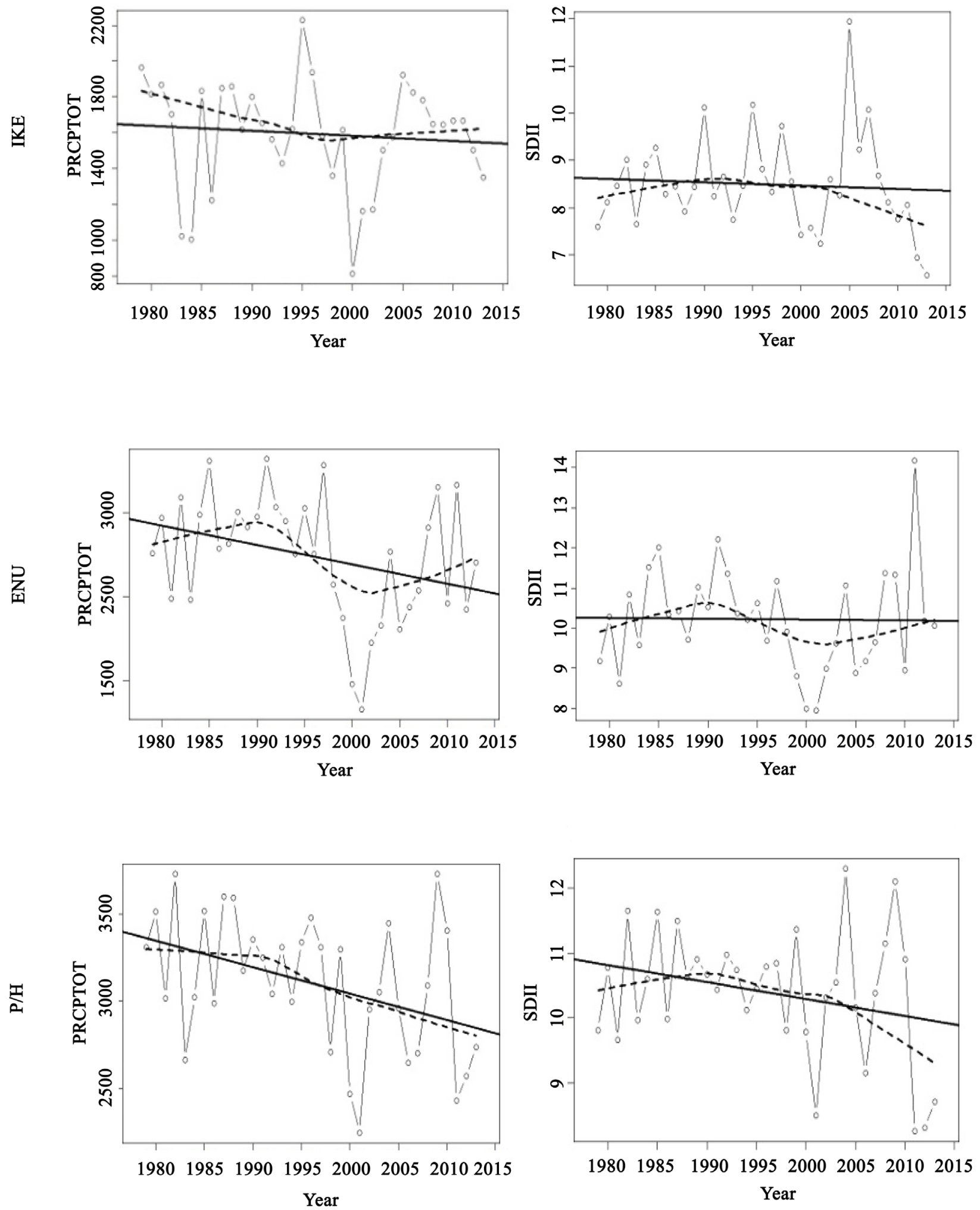

(i) PRCPTOT

(ii) SDII

(b)

Figure 7. (a): Temporal trends of yearly mean (i) PRCPTOT and (ii) SDII for selected stations in Nigeria (1979-2013); (b): Temporal trends of yearly mean (i) PRCPTOT and (ii) SDII for selected stations in Nigeria (1979-2013). 

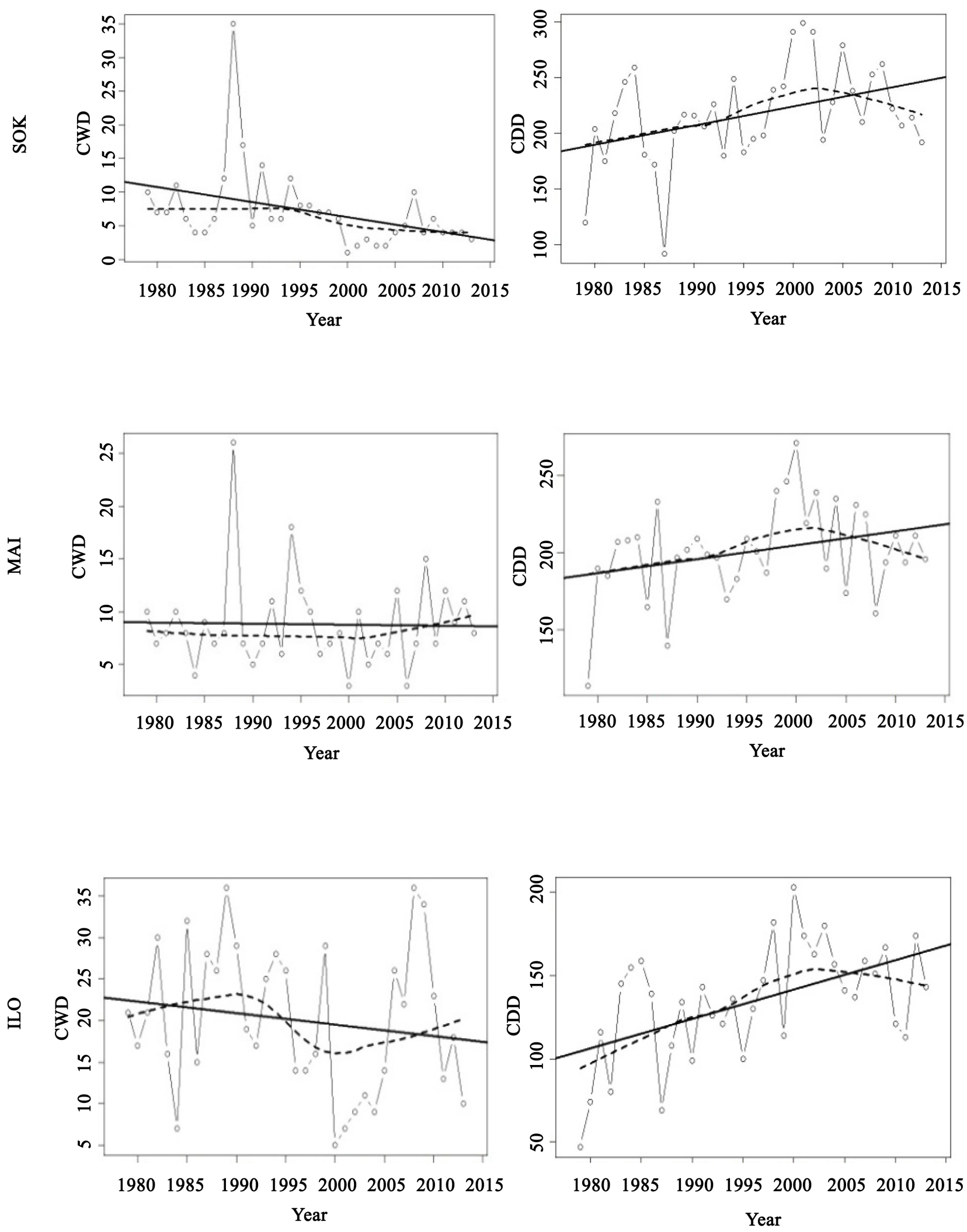

(i) CWD

(ii) $\mathrm{CDD}$

(a) 

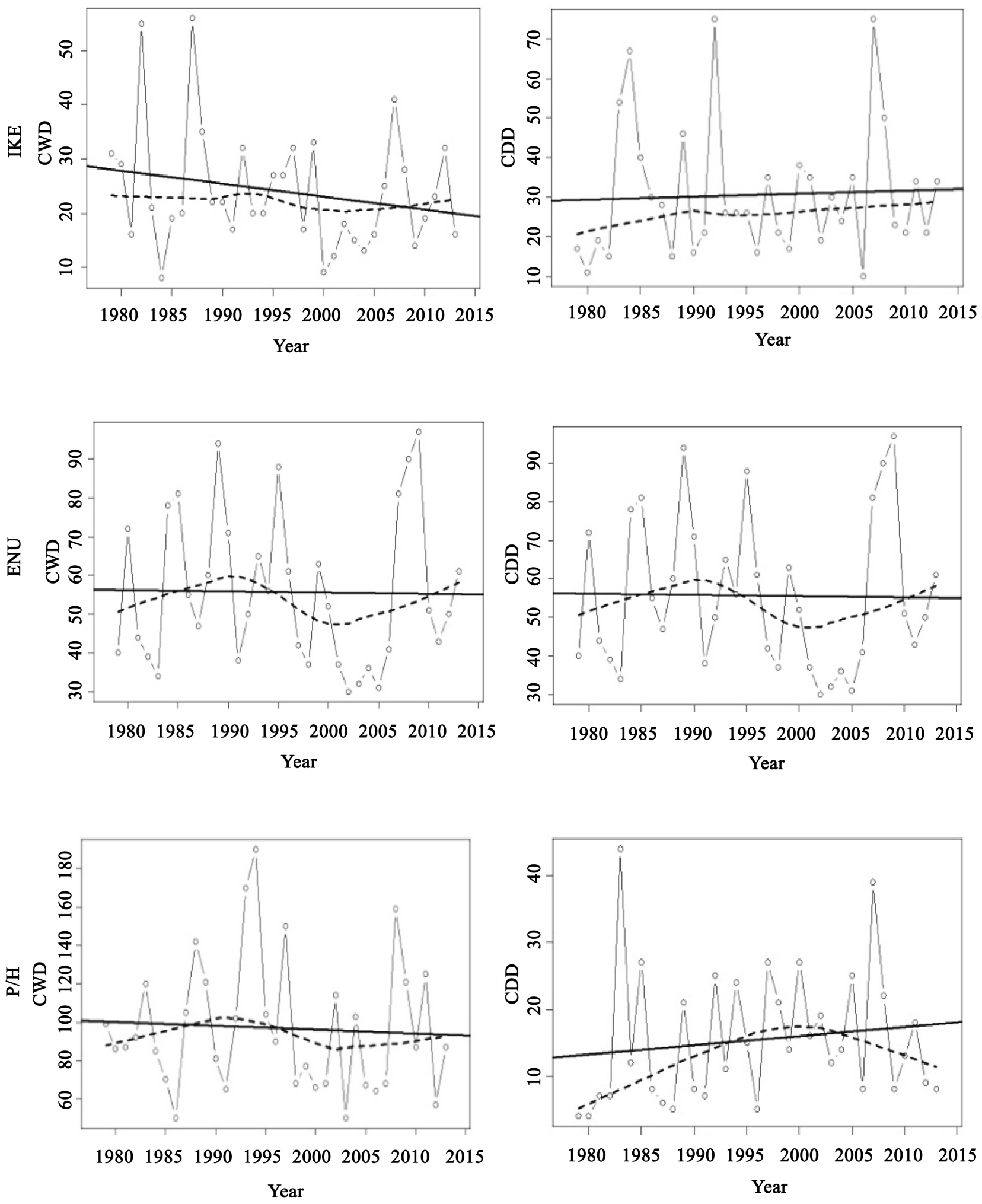

(i) CWD

(ii) CDD

(b)

Figure 8. (a): Temporal trends of yearly mean (i) CWD and (ii) CDD for selected stations in Nigeria (1979-2013); (b): Temporal trends of yearly mean (i) CWD and (ii) CDD for selected stations in Nigeria (1979-2013). 
CWD decreases in the period under study while the corresponding CDD increased. The increase in consecutive dry days (CDD) with decrease in the corresponding CWD is an indication that the country is trending toward a warmer and drier climate.

The spatial patterns and temporal trends of precipitation and precipitation extremes observed in this study could be the possible reasons for the precipitation extreme events (flooding, erosion, landslide, drought, etc) observed in Nigeria. These findings are clear indication of weather and climate extremes in the country.

We tend to attribute our findings to global warming-induced climate change which altered rainfall patterns leading to extreme events (i.e. flooding, drought) in contrast to the assumption by the general populace as normal recurrent events. According to (Iqbal et al., 2019; Benson et al., 2017), global warming-induced climate change altered rainfall patterns. The changes in precipitation and its extremes observed in this study may have severe implications on water resources and agriculture, among others.

\section{Conclusion and Recommendations}

1) Precipitation and its extremes indices varied spatially across Nigeria from one geographical location to another.

2) Decreasing trends were observed in most of the precipitation indices which could be the possible explanation for the erratic rainfall, drought, and desertification in most regions.

3) Furthermore, increase upward trends observed in RX1, RX5, and R99p could be the major cause of erosion, landslide and flooding in most regions in Nigeria.

4) The increase in CDD with the decrease in the corresponding CWD is an indication that the country is trending toward a warmer and drier climate.

5) The observed spatial and temporal changes indicate that Nigeria's climate is trending towards a warmer and drier condition.

6) These changes were attributed to global warming-induced climate change, which altered historical rainfall patterns thereby leading to extreme events.

7) The results of the analysis suggest the likelihood of severe impacts on water resources, agriculture, and water-sensitive economic activities.

8) For a better understanding of the observed extreme events in the country such as heatwaves due to extreme temperature, we hereby recommend further studies.

\section{Acknowledgements}

We thanked the Nigeria Meteorological Agency (NIMET), for the daily precipitation data used in this study. We are grateful to the Expert Team on Climate Change Detection and Indices (ETCCDI), the developer of the R source code that was used in this analysis. Thanks to the anonymous reviewers for their 
comments and suggestions that greatly improved the manuscript.

\section{Conflicts of Interest}

The authors declare that they have no known competing financial interests or personal relationships that could have appeared to influence the work reported in this paper.

\section{References}

Abaje, I. B. (2007). Drought and Desertification in Northern Nigeria: Implications for Sustainable Development. Journal of the School of Arts and Social Sciences, 1, 226-239.

Abaje, I. B., \& Giwa, P. N. (2010). Flood Risk Assessment and Vulnerability in Kafanchan Town, Jema'a Local Government Area of Kaduna State, Nigeria. International Journal of Sustainable Development, 3, 94-100.

Abaje, I. B., Ati, O. F., Iguisi, E. O., \& Jidauna, G. G. (2013). Droughts in the Sudano-Sahelian Ecological Zone of Nigeria: Implications for Agriculture and Water Resources Development. Global Journal of Human Social Science (B): Geography, Geo-Sciences and Environmental, 13, 1-10.

Akisanola, A. A., \& Ogunjobi, K. O. (2014). Analysis of Rainfall and Temperature Variability over Nigeria. Global Journal of Human-Social Science, 14, 1-17.

Audu, M. O., \& Okeke, F. N. (2018). Seasonal Variability of Rainfall and Its Decadal Anomaly over Nigeria: Possible Role of Solar and Geomagnetic Activities. International Journal of Advanced Engineering Research and Science, 5, 325-335. https://doi.org/10.22161/ijaers.5.9.39

Benson, N., Nwokike, C., Williams, A., Adedapo, A., \& Fred-Ahmadu, O. (2017). Changes in Diurnal Temperature and Precipitation Extremes in North Central Nigeria. The 2nd International Electronic Conference on Atmospheric Sciences, Basel, 16-31 July 2017, 1-12. https://doi.org/10.3390/ecas2017-04148

Chhabra, V., \& Haris, A. A. (2015). Climate Variability, Extreme Rainfall and Temperature Events over Different Agro-Ecological Zones of Bihar. Journal of AgriSearch, 2, 189-194.

CNN (2021). Africa's Most Populous City Is Battling Floods and Rising Seas. It May Soon Be Unlivable, Experts Warn. August 2.

Emily, J. P., \& Barry, D. K. (2014). Trends in Daily Temperature and Precipitation Extremes for the Southeastern United States: 1948-2012. Journal of Climate, 28, 1592-1612. https://doi.org/10.1175/JCLI-D-14-00410.1

Gajić-Čapka, M., Cindrić, K., \& Pasarić, Z. (2015). Trends in Precipitation Indices in Croatia, 1961-2010. Theoretical and Applied Climatology, 121, 167-177. https://doi.org/10.1007/s00704-014-1217-9

Gbode, I. E., Adeyeri, O. E., Menang, K. P., Intsiful, J. D. K., Ajayi, V. O., Omotosho, J. A., \& Akinsanola, A. A. (2019). Observed Changes in Climate Extremes in Nigeria. Meteorological Application, 26, 642-654. https://doi.org/10.1002/met.1791

Iqbal, Z., Shahid, S., Ahmed, K., Ismail, T., \& Nadeem, N. (2019). Spatial Distribution of the Trends in Precipitation and Precipitation Extremes in the Sub-Himalayan Region of Pakistan. Theoretical and Applied Climatology, 137, 2755-2769.

https://doi.org/10.1007/s00704-019-02773-4

Javanmard, S., Jamali, J., Yatagai, A., \& Mahdavi, E. (2011). Spatial and Temporal Analysis of Precipitation over Iran Using Gridded Precipitation Data of APHRODITE. Glob- 
al Environmental Research, 15, 157-164.

Kaah, P. M. (2017). Climate Extreme Indices Derived from Observed Daily Precipitation and Temperature Data over Cameroon: The Need for Further Assessments. Meteorological Applications, 24, 167-171. https://doi.org/10.1002/met.1628

Khan, M. J. U., Islam, A. K. M. S., Das, M. K., Mohammed, K., Bala, S. K., \& Islam, G. M. T. (2019). Observed Trends in Climate Extremes over Bangladesh from 1981 to 2010. Climate Research, 77, 45-61. https://doi.org/10.3354/cr01539

Khomsi, K., Mahe, G., Tramblay, Y., Sinan, M., \& Snoussi, M. (2016). Regional Impacts of Global Change: Seasonal Trends in Extreme Rainfall, Run-Off and Temperature in Two Contrasting Regions of Morocco. Natural Hazards and Earth System Sciences, 16, 1079-1090. https://doi.org/10.5194/nhess-16-1079-2016

Linden, A., David, J. K., \& Andrew, J. D. (2019). Historical Extreme Rainfall Events in Southeastern Australia. Weather and Climate Extremes, 25, Article ID: 100210. https://doi.org/10.1016/j.wace.2019.100210

Manta, D. N. (2010). Assessing Climate Variability Using Extreme Rainfall and Temperature Indices. University of Mauritius Research Journal, 16, 195-206.

Manton, M. J., Della-Marta, P. M., Haylock, M. R., Hennessy, K. J., Nicholls, N., Chabmer, L. E., Collins, D. A., Daw, G., Finet, A., Gunawan, D., Inape, K., Isobe, H., Kestin, T. S., Lefale, P., Leyu, C. H., Lwin, T., Maitrepierre, L., Ouprasitwong, N., Page, C. M., Pahalad, J., Plummer, N., Salinger, M. J., Suppiah, R., Tran, V. L., Trewin, B., Tibig, I., \& Yee, D. (2001). Trends in Extreme Daily Rainfall and Temperature in Southeast Asia and the South Pacific: 1961-1998. International Journal of Climatology, 21, 269-284. https://doi.org/10.1002/joc.610

Mbah, B. A. (2014). Challenges of Climate Change on Provision of and Accessibility to Quality Education in Nigeria. International Journal of Education Learning and Development, 2, 26-32.

Mohammed, M. U., Abdulhamid, A., Badamasi, M. M., \& Ahmed, M. (2015). Rainfall Dynamics and Climate Change in Kano, Nigeria. Journal of Scientific Research \& Reports, 7, 386-395. https://doi.org/10.9734/JSRR/2015/17098

Nashwan, M. S., \& Shahid, S. (2019). Spatial Distribution of Unidirectional Trends in Climate and Weather Extremes in Nile River Basin. Theoretical and Applied Climatology, 137, 1181-1199. https://doi.org/10.1007/s00704-018-2664-5

Soltani, M., Laux, P., Kunstmann, H., Stan, K., Sohrabi, M. M., Molanejad, M., Sabziparvar, A. A., SaadatAbadi, R., Ranjbar, F., Rousta, I., Zawar-Reza, P., Khoshakhlagh, F., Soltanzadeh, I., Babu, C. A., Azizi, G. H., \& Martin, M. V. (2015). Assessment of Climate Variations in Temperature and Precipitation Extreme Events over Iran. Theoretical and Applied Climatology, 126, 775-795. https://doi.org/10.1007/s00704-015-1609-5

Watson, D. F., \& Philip, G. M. (1985). A Refinement of Inverse Distance Weighted Interpolation. Geoprocessing, 2, 315-327.

Yin, H., \& Sun, Y. (2018). Characteristics of Extreme Temperature and Precipitation in China in 2017 Based on ETCCDI Indices. Advances in Climate Change Research, 9, 218-226. https://doi.org/10.1016/j.accre.2019.01.001

Zhang, X., \& Yang, F. (2017). RClimDex (1.1) User Guide. Climate Research Division ETCCDI/CRD Climate Change Indices. http://etccdi.pacificclimate.org/software.shtml 